\title{
Evaluating food systems in comprehensive planning: Is the Mississippi Gulf Coast planning for food?
}

\author{
Jennifer S. Evans-Cowley ${ }^{\mathrm{a}}$
}

Submitted 4 April 2011 / Accepted 22 July 2011 / Published online 30 October 2011

Citation: Evans-Cowley, J. S. (2011). Evaluating food systems in comprehensive planning: Is the Mississippi

Gulf Coast planning for food? Journal of Agriculture, Food Systems, and Community Development, 2(1), 105-126.

http://dx.doi.org/10.5304/jafscd.2011.021.009

Copyright (C) 2011 by New Leaf Associates, Inc.

\begin{abstract}
The Mississippi Gulf Coast is famous for its shrimp, oysters, and crabs. Seafood is an essential part of both the culture and the diet of coastal residents. The last five years have been hard on the seafood industry, due first to Hurricane Katrina, then the national recession, and then the Deepwater Horizon oil spill. In the five years following the hurricane, all of the cities and counties on the Mississippi Gulf Coast prepared comprehensive plans covering the future of the land use, public facilities, and housing for the community for 20 or

a Jennifer Evans-Cowley, City \& Regional Planning, The Ohio State University, 275 West Woodruff, Columbus, OH 43210 USA; +1-614-292-5427; cowley.11@,osu.edu

This paper is based on research supported by the U.S. Department of Housing and Urban Development Regional Sustainability Planning grant program.

Disclosure

The author is part of a HUD Regional Sustainability Planning grant supporting regional food system planning on the Mississippi Gulf Coast.
\end{abstract}

more years. This paper examines the degree to which food systems have been incorporated into the comprehensive plans developed on the Mississippi Gulf Coast. It finds that food systems have not been adequately integrated into the plans. The comprehensive plans for the region begin to touch on food systems, but fail to create a factual basis to support planning for those systems, such as identification of the proportion of retail food establishments that accept food assistance programs. They set limited goals to support food systems and propose limited implementation measures in support of them. While the region as a whole has not yet planned for food systems, there are instances where communities are examining the future of food. This article concludes by offering recommendations on how communities can improve their plans relative to food systems as they move into their next phase of regional planning.

\section{Keywords}

comprehensive plan, food system, Gulf Coast, Mississippi, plan evaluation, seafood 


\section{Introduction}

"Eat Local" is a phrase that is being heard more and more across the United States. While it sounds great, there are significant concerns about food safety, environmental impact, economic impact, and food quality for both local and imported food. On the Mississippi Gulf Coast, seafood is a local food that has had significant historical, cultural, and economic importance for the region. Innovations in canning, ship-building, and transportation in the region led to Biloxi, Mississippi, becoming the seafood capital of the world. By the midnineteenth century, the invention of artificial ice and the extension of the railroad system through the Mississippi Gulf Coast led to the commercialization of the seafood industry (MDMR, 2009). The first seafood cannery opened in Biloxi in 1881, and by 1890 it was processing two million pounds $(907,185 \mathrm{~kg})$ of oysters and 614,000 pounds $(278,506 \mathrm{~kg})$ of shrimp annually. There were 12 canneries processing almost six million pounds $(2,721,554 \mathrm{~kg})$ of oysters and 4.4 million pounds $(1,995,806 \mathrm{~kg})$ of shrimp by 1902 , and Biloxi was named the "Seafood Capital of the World" in 1903 (Mississippi Historical Society, n.d.). Seafood production continues to be an important industry on the Mississippi Gulf Coast. For example, in 2007 the Port of Pascagoula was ranked sixth nationally in terms of pounds of commercial seafood landed (NOAA, 2011).

While the seafood industry has continued to be of critical importance to the Gulf Coast, it is a threatened industry. In 2005, Hurricane Katrina destroyed many shrimping boats, processing facilities, and fishermen's homes. The hurricane also resulted in significant degradation of Mississippi's coastal environment, including substantial impact on such seafood habitat as the coastal marshes (Fletcher, 2007). Beyond the devastation of the natural environment there was substantial job loss across the coast, including in the seafood industry (NOAA, 2007). As the industry began to rebuild, the national recession resulted in decreased demand for Gulf Coast seafood and a more competitive global market, where imports competed with Gulf Coast seafood.
The Deepwater Horizon oil spill occurred off the coast of Pascagoula, Mississippi, on April 20, 2010, creating a massive "train wreck" along the Gulf Coast of Mississippi. Haeuber (1998) describes a "train wreck" as a clash between urban development and environmental protection objectives following a disaster. He suggests that an environmental disaster presents the opportunity for discussion about environmental goals that may not otherwise have occurred. He further argues that this collision of interests between different groups is instrumental in bringing about environmental protection efforts. The Deepwater Horizon oil spill directly affected the food system by contaminating seafood and the habitats of seafood. A "food system," for the purposes of this article, is defined as the sequence of activities tying together food production, processing, distribution, access, consumption, waste, and their associated regulatory institutions and activities (American Planning Association, 2007).

The combination of environmental and economic loss created a train wreck that has engaged the public, elected leaders, and the business community in challenging debates over how to recover. Creating a sustainable future following an event like an oil spill is a difficult balance, as it must include consideration of environmental protection, the food system, social equity, and economic development goals. Campbell (1996) describes the combination of environmental, economic, and social goals as the "planner's triangle," with sustainable development at the center. Campbell argues that planners must deal constantly with the conflicts between promoting these three goals. Over the last five years, the public and planners have worked together to create comprehensive plans that attempted to create a more sustainable future.

Community planning efforts were initiated immediately following Hurricane Katrina. Governor Barbour's Commission for Recovery, Rebuilding, and Renewal hosted the Mississippi Renewal Forum, which brought together more than 200 architects, planners, and community leaders to create initial rebuilding plans for each of the incor- 
porated communities along the Mississippi Gulf Coast (Mississippi Renewal Forum, 2005; EvansCowley \& Gough, 2009). In 2006, HUD provided funding to the Mississippi Development Authority to support comprehensive planning in Mississippi Gulf Coast cities and counties. The intent was to ensure that every Mississippi Gulf Coast community would have a comprehensive plan to guide its long-term changes. The grants were used by local governments to hire consultants to create comprehensive plans that met the needs of each individual community.

The HUD funding provided a unique opportunity for every community to simultaneously undertake comprehensive planning that could lead to a more sustainable and resilient future. Given the importance of the seafood industry, the author wondered whether communities integrated food systems into their comprehensive plans. As of June 2011, all of the communities along the Mississippi Gulf Coast had developed comprehensive plans, although three of the plans are still drafts and will soon be considered for adoption. The state of Mississippi's provision of expertise and financial assistance in initiating planning makes the Mississippi Gulf Coast an ideal location to compare planning efforts. It has 11 cities and three counties ${ }^{1}$ that simultaneously undertook planning under very similar conditions with similar levels of funding, thereby allowing for comparisons of plans. Mississippi statute sets minimum requirements for a comprehensive plan: it must coordinate physical development based on present and future needs and express public policy for the development of the community. The comprehensive plan must include long-range goals and objectives, a land use plan, a transportation plan, and a community facilities plan (State of Mississippi, 1972). Food is not required as a specific element, but can easily be included as part of the land use, transportation, and community facilities elements. For example, where food stores are located can be part of land use, and how the public accesses food stores can be addressed in transportation.

\footnotetext{
${ }^{1}$ These counties do the planning for unincorporated communities.
}

This study examines whether food is being considered as part of the planning for a more sustainable future of the Mississippi Gulf Coast. It seeks to answer three key research questions: (1) Are plans creating a factual basis to support decision-making that would support food systems? (2) Are plans setting goals and objectives in support of food systems? (3) Are plans proposing implementation strategies and policies that will support food systems? Support for the food system is determined by how the plan describes specifically how specific data, goals, or policies will improve some aspect of the food system.

The paper begins by focusing on selected literature related to food systems planning and plan evaluation. The methodology for this study is then discussed, followed by the results of the evaluation. The paper concludes with a discussion of policy decisions and recommendations for improving food system planning along the Mississippi Gulf Coast.

\section{Literature Review}

Food system planning has received little emphasis over the past few decades. A study of 22 U.S. planning agencies that had either a food policy council or active food organizations found that planning agencies are only lightly involved in food system planning (Pothukuchi \& Kaufman, 2000). The study found that the planners' role in the food system is generally reactive and piecemeal. Planners in these agencies reported being $50 \%$ or more involved only in the siting of food outlets, the design of food outlets, the siting and design of community gardens, and studies on the impact of the food sector on the local economy.

The result of the lack of integration of food system planning into the role of the city planner leads planners to fold grocery stores into general commercial development, without considering the high priority food plays in household needs. As another example, failure to devise comprehensive community-wide plans for composting food wastes results in their being disposed of in landfills. Planners responded that they are not engaged in food system planning because they only deal with the built 
environment, that food systems are a rural issue, that the food system is dominated by the private market, that planners are not funded to undertake food system planning, and that there isn't a problem (Pothukuchi \& Kaufman, 2000). Researchers have argued that the lack of integration of food system planning into the design of the city disproportionately impacts women. There have also been calls for designing neighborhoods with food features such as co-ops and community gardens (Franck \& Ahrentzen, 1989; Hayden, 1981, 1986; Tinker, 1995, 1997).

Raja et al. (2008) call for the inclusion of food as an element of comprehensive plans. They recommend that comprehensive plans integrate food destinations, foodscapes, neighborhood access, and connections between transportation and food sources. Food destinations include farmers' markets, while foodscapes are edible landscapes. Pothukuchi and Kaufman (2000) argue that planners should engage in food system planning by compiling data on the community food system, analyzing the connections between food and other planning issues, assessing the current impact of planning on the local food system, and integrating food security into community goals. These calls to action for planners tend to be land-based in their approach, yet for the Mississippi Gulf Coast land is only one piece of the food system challenge.

Much of the historic literature linking food systems and planning has focused on agricultural preservation (Daniels, 1991; Paster, 2004). This literature points to the importance of protecting agricultural land from development encroachment. However, development encroachment is important from another perspective on the Mississippi Gulf Coast.

Seafood is a particularly important part of the food system on the Mississippi Gulf Coast. While seafood has been highly valued culturally, it has been difficult to reconcile a desire to preserve the nurseries that support fishing with population growth and land development. Human activities are the leading cause of the loss of ecosystem integrity (Peck, 1998). Looking across the Mississippi Gulf Coast, fragmentation of natural drainage systems can be attributed to local planning decisions that have allowed development to repeatedly intrude into flood plains and wetland areas.

There is a direct link between land use policies and ecosystem health. Research has found that land use decisions affect the effective management of an ecosystem (Beatley, 2000; Endter-Wada, Blahna, Krannich, \& Brunson, 1998; Kirklin, 1995; McGinnis, Woolley, \& Gamman, 1999; Noss \& Scott, 1997). Because land use policies and plans affect the ecosystem, and in turn the availability of seafood, comprehensive plans are an important source of control. Deliberative comprehensive plans and follow-through on implementation can protect critical habitats that support seafood production (Duerksen, Elliott, Thompson, Johnson, \& Miller, 1997).

Food system protection can also be achieved through land use policies that discourage growth in flood-prone areas (Bechtol \& Laurian, 2005; Berke, Crawford, Dixon, \& Ericksen, 1999; Berke \& French, 1994; Brody, 2003; Godschalk \& Burby, 1999). Food system protection techniques can be regulatory, such as limiting development in a floodprone area, or voluntary, such as encouraging urban farming practices. Both types of strategies can be incorporated into local land use decisions, but they require that local governments engage in comprehensive planning to change the development patterns in the community.

Local governments are also looking to siting requirements as a tool for limiting or providing increased access to food, for example, through the siting of farmers' markets, fruit stands, and mobile food vendors in public and private spaces (Hernandez-Lopez, 2010; Morales \& Kettles, 2009). Other communities are reconsidering their limitations on urban animal husbandry (Duerksen, 2009).

Another way to promote the local food system is a locally grown food law that requires or provides incentives for purchasing food grown within a specific area. For example, cities are using locally grown food purchase policies that ensure that food 
for public facilities is purchased locally where possible. The goal of these policies is to allow for local producers to expand their market locally and increase food safety, support the local economy, reduce storage time, and create more transparency and accountability (Denning, Graff, \& Wooten, 2010).

The Mississippi Gulf Coast must determine the environmental impact on the estuaries, Mississippi Sound, and other areas affected by the oil spill, and how it can work with communities to clean up and protect these areas. The literature proposes that a disaster such as an oil spill may spur major environmental initiatives that can work in favor of protecting sensitive areas. Haeuber's (1998) description of the clash between urban development and environmental protection objectives following a disaster as a train wreck suggests that the Mississippi Gulf Coast is ripe for new environmental protection opportunities that could protect the food system.

Public officials and planners are charged with making complex decisions that meet environmental protection, social equity, and economic development goals following a train wreck (Blowers, 1993; Campbell, 1996). Planning for food systems is an example of a topic that has implications for environmental protection, social equity, and economic development. Campbell (1996) argues that sustainability may be very hard to achieve because of the difficulty in breaking the concept down into small implementable steps. There are also political challenges, where economic values may trump environmental or social values. What is more important: food security, seafood production, or estuary protection? Planners and public officials can find it difficult to solve the challenges facing food systems.

One way to address the complexity of these and other competing interests is through the use of collaborative planning that integrates the efforts of planners, public officials, and the public (Beatley, 1995; Blowers, 1993; Campbell, 1996). The participation of all parties can result in valuable exchanges of ideas about how to create a more sustainable food system. Public involvement in comprehensive planning is essential in bringing about change through supporting community farmers' markets, changing zoning regulations, and encouraging capital investment in harbor facilities. Several researchers have identified the "window of opportunity" phenomenon, in which public interest peaks after a focusing event, such as an oil spill, and then declines over time (Birkland, 1996, 1997; Lindell \& Perry, 1999; Prater \& Lindell, 2000). In collaborative planning opportunities, the public may feel empowered to make decisions about its future and hold ownership in the final plan (Daniels \& Walker, 2001; Innes, 1996; Roberts, 2006; Sowman \& Brown, 2006). Research has found that participation at the beginning of the planning process increases trust and support for environmental protection (Yaffee \& Wondolleck, 1997). Participatory planning processes can help members of the public understand their behaviors and how they affect the sustainability of the community (Adolfsson, 2002; Grant, Manuel, \& Joudrey, 1996). In a study of multijurisdictional environmental problems, researchers found that strong natural resource protection plans resulted from trust built through a collaborative planning process (Innes, 1996). In light of the recent oil spill and preceding hurricane, one could expect public interest in protecting natural resources to be high (Burby \& French, 1981; Wondolleck \& Yaffee, 2000).

Given the importance of food system planning, how can it best be incorporated into comprehensive plans? Protocols for evaluating comprehensive plans have been developed. The protocol and evaluation criteria used by numerous researchers, which are discussed in the following methodology section, were reviewed and evaluated for appropriateness to include in this evaluation.

\section{Methodology}

In order to answer the research questions in this study, each of the local governments on the Gulf Coast was contacted in winter 2011 to request a copy of their comprehensive plan. All 14 of the 
communities participated by providing copies of the comprehensive plans. ${ }^{2}$

\section{Coding Instrument}

In order to systematically evaluate the integration of food systems into the comprehensive plans, the methodology relies on a detailed plan evaluation protocol that is designed specifically for the evaluation of food systems. While seafood was an important aspect of this study, seafood represents just one part of the food system. Coastal communities should be planning for the entire food system, including seafood. This protocol is built on the idea that food systems can best be planned for if the community's comprehensive plan creates a factual basis for food systems that supports decision-making (such as identification of the proportion of retail food establishments that accept food assistance programs), sets goals and objectives, and identifies implementation strategies intended to advance the food system. Existing plan evaluation literature identifies standard methods for plan evaluation (Berke \& French, 1994; Berke et al., 1999; Chaplin \& Kaiser, 1979; Kaiser, Godschalk, \& Chapin, 1995; Srivastava \& Laurian, 2006). The method used in this study utilizes the protocols developed in previous evaluations of comprehensive plans (Baer, 1997; Berke \& French, 1994; Berke et al., 1999; Berke et al., 2006; Brody, 2003; Burby \& May, 1997; Evans-Cowley \& Gough, 2007, Evans-Cowley \& Gough, 2008; Laurien et al., 2004; Norton, 2006; Srivastava \& Laurian, 2006). However, the previous plan evaluations examined food systems on a very limited basis. The criteria for evaluation in these previous studies have some elements related to food systems, such as the use of transfer of development rights as a policy. In order to develop criteria to evaluate plans, the author examined indicators used in the previous studies and examined those developed to measure healthy and sustainable communities, such as the Healthy Development Measurement Tool used by

\footnotetext{
${ }^{2}$ One community declined to provide a copy of its plan, citing that it had not yet been adopted by the city council. The researcher was able to obtain a copy of the draft plan, which was at the time being presented in public meetings, from another planning agency in the region.
}

the San Francisco Department of Public Health and the Sustainable Community Development Code Framework (San Francisco Department of Health, 2006; Duerksen, 2009). The literature points to important potential indicators. For example, Pothukuchi and Kaufman (2000) recommend that data about local food and food security be collected as part of the planning process. This led to the author's inclusion of factual basis measures in the plan evaluation, such as identification of the proportion of retail food establishments that accept food assistance programs. A number of researchers point to the importance of agricultural preservation (Daniels, 1991; Duncan, 1984; Paster, 2004), which led to the inclusion of a goal indicator "concentrate growth away from agriculture." There is a wide array of potential implementation policies and strategies that can support food systems, for example, siting farmers' markets and permitting mobile food vendors, both of which were included as indicators (Hernandez-Lopez, 2010; Morales \& Kettles, 2009). Local food purchasing policies is another example that emerged from the literature (Denning et al., 2010).

A total of 57 indicators are used to evaluate the plans (see appendix, table 1). Twenty-four indicators are used to evaluate the factual basis of food systems, which assists in providing adequate information upon which goals and policies can be set. Seven indicators are used to evaluate plan goals and objectives. Twenty-six indicators are used to determine strategies to achieve food system goals.

\section{Coding Process}

Each comprehensive plan indicator was evaluated on a scale of zero to two. For the factual basis, a score of zero indicates that the criteria was absent in the plan. A score of one indicates that criteria was present but not detailed, and two indicates that the criteria was present and detailed. For example, if a plan does not discuss farmers' markets, a score of zero would be marked. If the plan mentions farmers' markets but provides no detail, it would receive a score of one. For a plan that has a detailed explanation of farmers' markets, including discussion of the location of markets and types of food products, a score of two would be marked. 
For goals, a zero is assigned if that indicator was absent. One indicates that the indicator was present and recommended, and two indicates that the indicator was present and required. For example, one of the indicators is the strengthening of the local and regional economy by promoting local and regional food systems. The Biloxi comprehensive plan received a score of two on this goal because it includes the following: "Ensure that the commercial seafood industry remains a vital part of Biloxi's economy, heritage, and appeal as a premiere visitor destination" (City of Biloxi, 2010, p. 131).

Following the initial development of the plan evaluation indicators, a colleague reviewed the criteria and provided feedback. Mississippi Gulf Coast planners then gave feedback on the criteria. Based on suggestions from these professionals the indicators were finalized. Each plan was then reviewed and coded. The author evaluated a trial plan in a community outside of Mississippi, identifying questions related to interpretation and refining the protocol until it was standardized.

\section{Score Calculation}

Scores were calculated in three steps. In the first step, we totaled the scores in each evaluation by category. For example, a plan might receive nine out of 16 points in the goals category. In the second step, we totaled the score across all categories. In the third step, we divided this score by the total number of points available to create a percentage score. Each category carried an equal weight. Due to the different number of indicators in each category, an averaged percentage score is calculated by summing the percentage score in each of the three categories and dividing by three, resulting in a normalized score. Higher percentage scores indicate a higher degree of integration of food systems. The overall plan score represents the degree to which the plan has a factual basis, specifies food system goals and objectives, and includes implementation strategies for achieving the plan's food system goals. In this paper, the percentage scores by category and for the entire plan, rather than individual point scores, are reported.

\section{Results}

While the author believed that there would be variation in the degree to which the plans address food systems, the fact that many simply did not address food systems at all was surprising, especially since seafood is such an important part of both the historical development of the region and its current economy. The average percentage scores of the comprehensive plans across categories ranged from $3.9 \%$ to $38.8 \%$ (see table 1). The highest score was for Harrison County, whose plan contains a Healthy Communities chapter that specifically focuses on food-system related proposals. For example, one of the actions is to build farmers' market pavilions onto existing community centers in the rural areas of the county (see figure 1) (Harrison County, 2008). This plan has a goal to increase access to healthy food options in Harrison County (Harrison County, 2006a).

\section{Factual Basis}

The plans generally received low scores for the factual basis for food systems, with Long Beach's plan receiving the lowest score, just $4.2 \%$ of the available points. Some of the factors that contribute to the low scores include plans that do not identify the location of food production facilities and/or that do not appropriately identify preservation areas as wetlands or flood plains. Some plans omit natural and environmental elements altogether, such as Long Beach, whose plan emphasizes urban redevelopment but never discusses the community's environmental conditions and their relationship to support of the food system.

The Harrison County comprehensive plan received the highest factual basis score of $29.2 \%$. The county has some agriculture as well as a fish hatchery, both of which resulted in some emphasis on food systems. Additionally, its plan includes data about the preventable disease incidence associated with an unhealthy diet (Harrison County, 2008). Biloxi, Ocean Springs, and Pascagoula both scored more than $18 \%$ on factual basis indicators. Both Biloxi and Pascagoula identified the historical role of food systems in their communities. For example, Biloxi was referred to as "the seafood capital 


\section{Figure 1. These Proposed Shade Structures Would Provide Protection for Farmers at Harrison County Farmers' Markets}

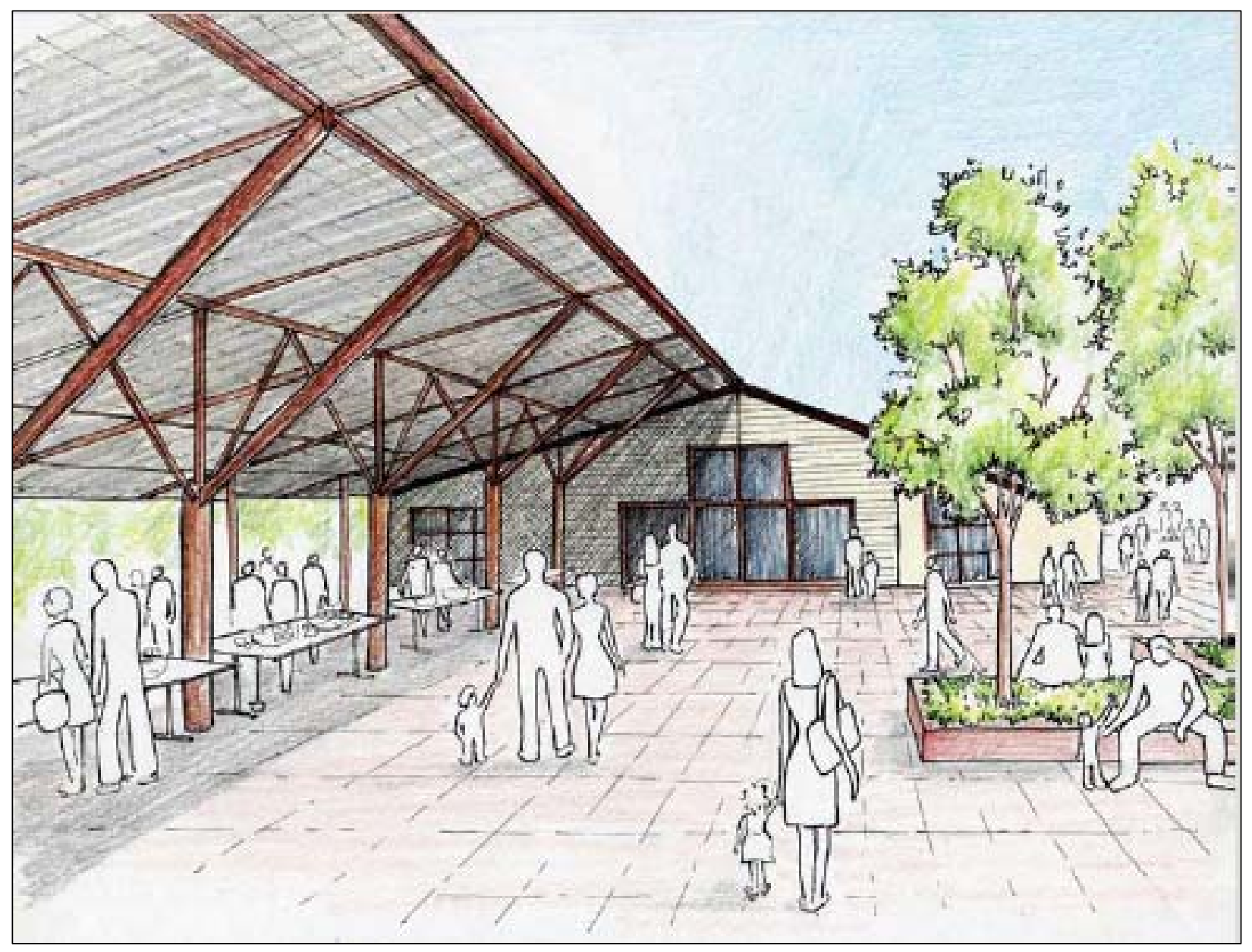

Source: Remya Kumar

of the world" at the turn of the twentieth century because of its pioneering work in seafood canning (City of Biloxi, 2010). Ocean Springs identified the local food bank (City of Ocean Springs, 2010). All of these communities focused on documenting physical areas and facilities that support mariculture.

\section{Goals and Objectives}

Eight of the 12 plans examined did not have any goals or objectives that directly support food systems. The four remaining plans varied in their supportive goals. Food systems were also considered from an economic perspective. Pass Christian's plan emphasizes the importance of rebuilding the harbor because $97 \%$ of the oysters harvested in Mississippi come from the reefs off Pass Christian (City of Pass Christian, 2006). Harrison County also focuses on the economics of food systems by supporting the economic vitality of the commercial and charter fishing industries (Harrison County, 2008). Based on the fact that the goals and objectives in many of the plans resulted from direct citizen input, it appears that citizens tend to be more interested in economic development than food systems.

Other plans viewed food systems from alternative perspectives. For example, Hancock County and Gautier County support the separation of devel- 
opment from agricultural areas. Harrison County's plan was the most specific about access to food by residents. For example, its objectives include improving food access, promoting community gardening, promoting farmers' markets, and developing a land bank to bring vacant and abandoned properties into agriculturally productive use (Harrison County, 2008).

\section{Policies, Tools, and Strategies}

Because only a limited number of plans had goals and objectives related to food systems, it is not surprising that the plans promote a limited number of policies, tools, and strategies for achieving food system goals. The plans scored poorly for their strategies for supporting food systems, ranging from $3.7 \%$ to $46.3 \%$. It is important to note that a number of the strategies could reach the same goal, so a low score by and of itself does not mean that a plan did not consider tools for achieving food system goals.

The key focus of the implementation measures was seafood. Where there were food system goals, they were primarily posed from an economic development perspective. Not surprisingly, many of the implementation strategies are also from an economic development perspective, including improving physical facilities and implementing land use policies to support working waterfronts.

For example, Biloxi, Gulfport, and Pass Christian have plans to expand the physical infrastructure that supports the seafood industry (City of Biloxi, 2009; City of Gulfport, 2010; City of Pass Christian, 2006). These would be achieved in different ways. For example, Gulfport is creating a new marina to support recreational and commercial charter fishing, while Pass Christian is supporting the movement of shrimpers to their harbor. A number of the communities, including Hancock County, Harrison County, and Biloxi, identified land use as an opportunity to support the seafood industry through working waterfronts (Hancock County, 2008). Biloxi's plan (2009) has a series of strategies that directly support the seafood industry, including:
- "Enact LDO [Land Development Ordinance] provisions and other strategies to support the seafood industry, other working waterfront uses, and recreational uses" (p. 22)

- "Limit industrial uses, other than seafood industry related, on the Peninsula" (p. 25)

- "Create a waterfront/commercial seafood district” (p. 36)

- "The proposed Seafood Village on the Back Bay... would provide dedicated berthing space for the commercial fishing fleet and processing facilities while also serving as a tourist attraction and destination with a seafood market" (p. 83)

Other communities, such as Biloxi, Long Beach, Moss Point, and Jackson County, are focusing on enhancing water access for tourism and recreational access (City of Biloxi, 2009; City of Gautier, 2009; City of Moss Point, 2009; Hancock County, 2008; Jackson County, 2009). Long Beach, for example, plans to create a harbor district that would cater to recreational boaters (City of Long Beach, 2010).

Interestingly, Waveland is the only community that mentions sustainability in this context, suggesting that the city should build a sustainable marine facility; however, no further detail is provided (City of Waveland, 2009).

Beyond promoting water access, the plans also promote the use of buffering along waterfronts particularly bayous and rivers - and support the clustering of development away from natural resources. Fifty-seven percent of plans include provisions for either clustering or buffering. A number of the plans mention wetlands preservation and other conservation efforts, yet in only one of the plans is conservation tied to fishing: Bay St. Louis proposes acquiring wetlands to support nurseries for fisheries (City of Bay St. Louis, 2008). Education centered around marine life, and the seafood life cycle, was a strategy in two communi- 
ties (City of Gulfport, 2010; City of Bay St. Louis, 2008).

The implementation strategies in the plans primarily focused on seafood, yet there were a few instances where communities identified additional opportunities in the food system. The implementation efforts were focused on community gardens, urban agriculture, and farmers' markets (City of Bay St. Louis, 2008; City of Biloxi, 2009; City of Moss Point, 2009; Harrison County, 2008; Jackson County, 2009). Figure 1 illustrates the Harrison County Farmers' Market concept, which would build shaded, open additions onto existing community centers to provide access to farmers' markets in the rural areas of the county.

\section{Overarching Results}

Prior research supports the findings of the present study. Pothukuchi and Kaufman (2000) examined 22 cities and found that food system planning was happening in a very limited way. For example, planners are engaged in siting of grocery stores. This trend was similar on the Mississippi Gulf Coast, as "food system" goals tended to be focused on tourism and economic opportunity rather than food production or food security.

Conroy and Berke (2004) found that the use of sustainability concepts, such as a healthy food system, did not translate into development of policies, and that even though plans may be created with the principles of sustainability, the results often lack sustainable development implementation strategies. Similar to these findings, all the plans encouraged sustainable development, but the implementation strategy scores remained low because of their lack of focus on food.

While the overall results of this study point to a lack of focus on food, one plan did show a significant focus on food: Harrison County. The zoning administrator for the county at the outset of the plan requested that this plan "be the most sustainable plan on the coast" (P. Bonck, Harrison County Zoning Administrator, personal communication, January 4, 2007). This plan specifically identified healthy communities as a key element to consider for the future. The plan has an extensive factual basis to inform the plan making, considering everything from soil suitability to diet-related diseases. This plan was supplemented by a citizen participation process that is well-documented in the plan, which specifically included questions about where people shop, what is missing from their grocery stores, and whether they need better access to food. There are clear connections between what the citizens said they want for their community and the plan's goals and objectives. The plan identified clear implementation policies, such as adopting an edible landscaping ordinance. The overall result has been tremendous community and political support for the plan and its implementation. As an example, since 2005 three new farmers' markets have been created in Harrison County. Participants in the planning process created a nonprofit organization, Real Food Gulf Coast, ${ }^{3}$ dedicated to growing and supporting a sustainable food economy on the Mississippi Gulf Coast. This organization emerged from an alliance of two farmers' market managers who were committed to making sure the people of the coast understand where their food comes from and to promote regional production and direct sales of these foods to consumers.

The Harrison County plan points to the potential for broader food system planning in the region. How can plans be improved to better address food systems? The conclusion of this paper addresses ways that Mississippi Gulf Coast communities can better plan for food systems.

\section{Conclusion}

The author expected that because food system planning is an emerging issue for professional planners, the level of inclusion of food system elements in the Gulf Coast comprehensive plans evaluated would be low, particularly as they relate to issues such as food security. However, given the importance of the seafood industry, the author expected that there would be inclusion of significant plan elements related to seafood. The degree

\footnotetext{
${ }^{3}$ Real Food Gulf Coast's website is http://www.realfoodgulfcoast.org
} 
to which food systems are incorporated into the community plans varied. Some communities integrated food systems well, while others failed to integrate them into their plans almost altogether. In part this may be a result of the small size and limited capacity of some communities; in other cases it may be because community members have not flagged food as a significant issue. Where food systems were included, there was a clear emphasis on the seafood industry. This emphasis focused primarily on community facilities, with limited attention to the land use and transportation issues that also affect the food system. In the communities where seafood was not emphasized, the emphasis was on expansion of ports and other facilities that support global trade, including foodstuffs. Given that comprehensive plans in Mississippi are expected to cover all three of these areas (land use, transportation, and community facilities), one would hope to see the intersections of food with these topics considered.

One can argue that food is an essential element of sustainability, and therefore considering the intersection of food with issues of economic, equitable, and environmental sustainability should be a part of comprehensive planning efforts. One partial explanation of why plans didn't robustly consider food may be the degree of complexity of the social, economic, and environmental problems facing the region in the wake of Hurricane Katrina. Campbell (1996) argues that planners have not yet determined how to get to sustainable development, which may be why the plans have not been effectively able to balance economic, social, and environmental needs. The literature suggests that in the aftermath of a natural disaster there will be a high degree of interest in integrating environmental protection measures, which could protect the food system (Birkland, 1996, 1997; Blowers, 1993; Burby \& French, 1981; Campbell, 1996; Lindell and Perry, 1999; Prater and Lindell, 2000). Yet this study found that for planners, economic development was more important than environmental protection as it relates to food systems. In the Gulf Coast region, both citizens and local officials were clearly focused on the immediate challenges of rebuilding housing and creating jobs, rather than on longer- term issues such as the preservation of farmland or seafood habitat.

While this article finds that the comprehensive planning efforts on the Mississippi Gulf Coast have examined food systems on a limited basis, there is optimism for the future. HUD recently awarded the Gulf Regional Planning Commission a US $\$ 2$ million grant to undertake a regional sustainability planning process. The plan will include an element called "Savor the Coast: A recipe for regional food system sustainability," that will address the regional food system. This provides an opportunity for the region to work together to address food system challenges.

In guiding this effort and other planning efforts the author has several key recommendations. To combat the idea that food is a rural issue that is outside the bounds of the jurisdiction, planners should consider the foodshed, a geographic area where foods can be grown (Getz, 1991). Communities should understand where their food comes from and how they access it. This could include a historical review of agriculture production in the foodshed, estimates of the ability of the foodshed to produce enough food to feed the population, identification of seasonal foods, and opportunities for urban agriculture (Feenstra, 1997). Examining food insecurity factors such as distance to food stores, income, and transit accessibility can lead to an understanding of neighborhood-level conditions that can lead to solutions supporting access to healthy food (Raja et al., 2008).

Elevating the importance of food planning can be achieved through stronger engagement of food system stakeholders. By creating stronger collaborative planning processes that integrate all stakeholders, from the low-income resident to the seafood processor, communities can develop a higher level of interest in planning (Godschalk, Brody, \& Burby, 2003; Innes, 1996). In the case of the Mississippi Gulf Coast there can be regional collaboration to take on food system planning through its regional sustainability planning process. Other ways to support stakeholder engagement could include a city creating a department of food, 
regions creating a food policy council, and city planning departments supporting the work of food system planning (Pothukuchi \& Kaufman, 1999).

The comprehensive plans in this study minimally discussed food organizations. Where there was discussion it was typically about regulatory or funding agencies, such as the Mississippi Department of Marine Resources. As part of the planning process, there should be efforts to reach out to organizations such as Real Food Gulf Coast, the Mississippi Gulf Coast Seafood Association, the Farm Service Agency, the Mississippi Food Policy Council, and others that bring together individuals with an interest in the food system. In addition to engaging local stakeholders, it will also be important to engage regional, state, and federal agencies and organizations that are conducting research and making decisions directly related to food systems. For example, the Mississippi Food Policy Council, Mississippi State University's Extension Service and Coastal Research Center, the Mississippi Department of Agriculture and Commerce, the Mississippi Department of Marine Resources, and the Gulf Coast Fisheries Council are all examples of key organizations that can be engaged in local food system planning.

All these organizations can be partners in gathering factual information, and identifying challenges facing the food system and strategies to collectively support the development of the local food system. Working in partnerships would help start the challenging discussions about where development and investment in the food system are most appropriate.

There are a number of regulatory measures and policy tools that are available to local governments. Morales and Kettles (2009) call for revising vendor ordinances. Currently on the coast there is mobile vending of shrimp. A study of mobile vending, evaluating the opportunities for expanded healthy food access is one option. Incentivizing the siting of food stores that carry healthy food choices is another option. Food purchasing and diversion policies could be adopted by large-scale institutional consumers to support the local food system.
Land use policies that support food systems by designating areas for food processing and food distribution, as well as preserving land for food production, can support the food system. An example of such a policy in action might be the creation of seafood hubs to allow for the seafood value chain to be centered in one location.

Supporting the food chain could also include consideration of policies to support mobile meat processing. Farmers on the Mississippi Gulf Coast note that they have to drive their cattle to Alabama because there are no processing facilities on the coast. Policies that would support cottage-scale food processing can provide the opportunity for small growers to add value to their products. Permitting programs for direct market sales of produce, meat, and seafood should be considered.

Currently the Mississippi Department of Health's regulations can be prohibitively onerous for small producers and processors who are trying to market their products directly. For example, shrimp can only be sold by the fisher if there is no processing. Removal of the heads is considered processing. However, even this minimal level of processing would make the product more desirable for consumers. While Mississippi has a farm to school program, only 10 farmers participate because the barriers to entry are high. A new effort might be starting up a sea to school program, increasing access to local food for schoolchildren. The Women, Infant, and Children (WIC) program is currently delivered through a county distribution center system. Changing the system to allow WIC recipients to redeem their benefits in local grocery stores would increase both redemption rates and access to healthy food by needy families. Regulations on backyard and large-scale composting and biogas facilities should be evaluated. These are just a few examples of the types of policies and regulations that could be included as part of food system planning.

Beyond regulatory and policy implementation, significant economic development opportunities exist. Small grant and loan programs can create significant opportunities for diversity in the availability of 
local foods which would increase market opportunities for producers and processors. A small loan program to support high tunnel greenhouses would allow for a longer growing season for fruits and vegetables. A small grant from Market Umbrella allowed the start-up of a community supported fishery (CSF) in New Orleans. The CSF used the grant funds to purchase insulated bags that were provided to each customer, who was then able to pick up the weekly share at a local farmers' market and safely carry it home.

Pennsylvania's Fresh Food Financing Initiative provides funding to support the provision of fresh food in food-insecure neighborhoods. Another possibility is a farmer and fisher co-op that can jointly put together fresh market baskets that can be delivered to food-insecure neighborhoods and could be paid for with Supplemental Nutrition Assistance Program (SNAP) benefits. Prior to Hurricane Katrina there were seafood markets at harbors. Bringing these markets back would allow fishers to sell directly to consumers at the docks. The image of Gulf Coast seafood was negatively affected by the Deepwater Horizon oil spill. "Buy Fresh-Buy Local” campaigns could boost local seafood sales, along with other locally produced foods.

Beyond grants and loans, providing facilities can benefit the community. A number of the plans promoted the idea of adding farmers' markets. The plans should be specific about what type of farmers' market is desired. Is it a market for locally produced food, or is it a produce market that provides access to resold produce, or some other market that may integrate nonfood goods such as arts and crafts? Markets serve many purposes. If the goal is to promote the local food system, this should be explicit in the promotion of local farmers' markets. Another example of a community facility is a commercial community kitchen, which can provide small start-up businesses with a place to process their food. Providing economic development incentives that focus on locally driven job creation can support the food system by allowing small food businesses the opportunity to grow. Many of the region's food pantries are located in neighbor- hoods affected by hurricanes. Consideration should be given to hurricane-proofing critical food distribution facilities.

A robust food system planning effort will consider all aspects of the food system and make culturally appropriate determinations as to which goals and implementation strategies are most appropriate. The Mississippi Gulf Coast provides an example of a region where food system planning efforts can be improved. With the current sustainability planning effort underway, there is significant promise that regional food system planning will be enhanced. There is a need for further research to explore the success of implementation strategies for food systems that emerge from comprehensive planning efforts.

\section{References}

Adolfsson, J. S. (2002). Local agenda 21 in four Swedish municipalities: A tool towards sustainability? Journal of Environmental Planning and Management, 45(2), 219-244. http://dx.doi.org/10.1080/09640560220116314

American Planning Association (APA). (2007). American Planning Association policy guide on community and regional food planning. Prepared for the American Planning Association's Legislative and Policy Committee.

Baer, W. C. (1997). General plan evaluation criteria: An approach to making better plans. Journal of the American Planning Association, 63(3), 329-344. http://dx.doi.org/10.1080/01944369708975926

Beatley, T. (2000). Preserving biodiversity: Challenges for planners. Journal of the American Planning Association, 66(1), 5-20. http://dx.doi.org/10.1080/ $\underline{01944360008976080}$

Beatley, T. (1995). Planning and sustainability: The elements of a new (improved?) paradigm. Journal of Planning Literature, 9(4), 383-395. http://dx.doi.org/10.1177/088541229500900405

Bechtol, V., \& Laurian, L. (2005). Restoring straightened rivers for sustainable flood mitigation. Disaster Prevention and Management: An International Journal, 14(1), 6-19. http://dx.doi.org/10.1108/ $\underline{09653560510583806}$

Berke, P. R. (2002). Does sustainable development offer a new direction for planning? Challenges for the twenty-first century. Journal of Planning Literature, 17, 21-36. http://dx.doi.org/10.1177/ $\underline{088122017001002}$ 
Berke, P. R., \& French, S. P. (1994). The influence of state planning on local plan quality. Journal of Planning Education and Research, 13(4), 237-250. http://dx.doi.org/10.1177/0739456X9401300401

Berke, P. R., Backhurst, M., Day, M., Ericksen, N., Laurian, L., Crawford, J., \& Dixon, J. (2006). What makes plan implementation successful? An evaluation of local plans and implementation practices in New Zealand. Environment and Planning B: Planning and Design, 33, 581-600. http://dx.doi.org/10.1068/b31166

Berke, P. R., Crawford, J., Dixon, J. E., \& Ericksen, N. J. (1999). Do cooperative environmental planning mandates produce good plans? Empirical results from the New Zealand experience. Environment and Planning B: Planning and Design, 26, 643-664. http://dx.doi.org/10.1068/b260643

Birkland, T. A. (1996). Natural disasters as focusing events: Policy communities and political response. International Journal of Mass Emergencies and Disasters, 14(2), 221-243.

Birkland, T. A. (1997). After disaster: Agenda setting, public policy, and focusing events. Washington, D.C.: Georgetown University Press.

Blowers, A. (1993). The time for change. In A. Blowers (Ed.), Planning for a Sustainable Environment (pp. 118), London, UK: Earthscan.

Brody, S. D., Godschalk, D. R., \& Burby, R. J. (2003). Mandating citizen participation in plan making. Journal of the American Planning Association, 69(3), 245-264. http://dx.doi.org/10.1080/ $\underline{01944360308978018}$

Brody, S. D. (2003). Measuring the effects of stakeholder participation on the quality of local plans based on the principles of collaborative ecosystem management. Journal of Planning Education and Research, 22, 407-419. http://dx.doi.org/10.1177/ 0739456X03022004007

Burby, R. J., \& French, S. (1981). Coping with floods: The land use management paradox. Journal of the American Planning Association, 47(3), 289-300. http://dx.doi.org/10.1080/01944368108976511

Burby, R. J., \& May, P. J. (1997). Making governments plan: State experiments in managing land use. Baltimore, Maryland: Johns Hopkins Press.

Campbell, S. (1996). Green cities, growing cities, just cities? Urban planning and the contradictions of sustainable development. Journal of the American Planning Association, 62, 296-313. http://dx.doi.org/ $\underline{10.1080 / 01944369608975696}$

Chaplin, S., \& Kaiser, E. (1979). Urban land use planning.
Champaign, Illinois: University of Illinois Press. City of Bay St. Louis. (2008). Bay St. Louis comprehensive plan update. Bay St. Louis, Mississippi: Author.

City of Biloxi. (2010). City of Biloxi comprehensive plan. Biloxi, Mississippi: Author.

City of Gulfport. (2010). Gulfport 2030 comprehensive plan. Gulfport, Mississippi: Author.

City of Long Beach. (2009). Long Beach, Mississippi, comprehensive plan. Long Beach, Mississippi: Author.

City of Ocean Springs. (2010). City of Ocean Springs comprehensive plan. Ocean Springs, Mississippi: Author.

City of Pass Christian. (2006). The City of Pass Christian comprehensive plan. Retrieved from http://www.ci.pass-christian.ms.us/2compplan 20061026.pdf

Conroy, M. M., \& Berke, P. R. (2004). What makes a good sustainable development plan? An analysis of factors that influence principles of sustainable development. Environment and Planning A, 36(8), 1381-1396. http://dx.doi.org/10.1068/a367

Daniels, T. L. (1991). The purchase of development rights: Preserving agricultural land and open space. Journal of the American Planning Association, 57, 421-431.

Daniels, S. E., \& Walker, G. (2001). Working through environmental conflict: The collaborative learning approach. Westport, Connecticut: Praeger.

Denning, B. P., Graff, S., \& Wooten, H. (2010). Laws to require purchase of locally grown food and constitutional limits on state and local government: Suggestions for policymakers and advocates. Journal of Agriculture, Food Systems, and Community Development, 1(1), 139-148. http://dx.doi.org/ 10.5304/jafscd.2010.011.014

Duerksen, C., Elliot, D., Thompson, N., Johnson, E., \& Miller, J. (1997). Habitat protection planning: Where the wild things are (APA Planning Advisory Service Report No. 470/471) American Planning Association: Chicago.

Duerksen, C. (2009). Sustainable community development code framework. Denver, Colorado: University of Denver Sturm College of Law. Retrieved from http://law.du.edu/index.php/rmlui/rmluipractice/code-framework

Endter-Wada, J., Blahna, D., Krannich, R., \& Brunson, M. (1998). A framework for understanding social science contributions to ecosystem management. Ecological Applications, 8(3), 891-904. http://dx.doi.org/10.1890/10510761(1998)008[0891:AFFUSS]2.0.CO;2 
Evans-Cowley, J. S., \& Gough, M. Z. (2007). Is hazard mitigation being incorporated into post-Katrina plans in Mississippi? International Journal of Mass Emergencies and Hazards, 25(3), 177-217.

Evans-Cowley, J. S., \& Gough, M. Z. (2008). Evaluating environmental planning in post-Katrina plans in Mississippi? Journal of Environmental Planning and Management, 51(3), 399-419.

Evans-Cowley, J. S., \& Gough, M. Z. (2009). Evaluating New Urbanist plans in post-Katrina Mississippi. Journal of Urban Design, 14(4), 439-461.

Feenstra, G. W. (1997). Local food systems and sustainable communities. American Journal of Alternative Agriculture, 12(1), 28-36. http://dx.doi.org/10.1017/S0889189300007165

Fletcher, M. (2007). Hurricane Katrina impacts and responses in pristine coastal salt marsh estuary. Retrieved from University of South Carolina website: http://www.sc.edu/katrinacrisis/fletcher.shtml

Franck, K. A., \& Ahrentzen, S. (Eds.) (1989). New households, new housing. New York, New York: Van Nostrand Reinhold.

Getz, A. (1991, October). Urban foodsheds. The Permaculture Activist, 24, 26-27.

Godschalk, D. R., \& Burby, R. (1999). Unleashing the power to create disaster-resistant communities. Journal of the American Planning Association, 65(3), 247-258.

Godschalk, D. R., Brody, S., \& Burby, R. (2003). Public participation in natural hazard mitigation policy formation: Challenges for comprehensive planning. Journal of Environmental Planning and Management, 46(5), 733-754. http://dx.doi.org/10.1080/ 0964056032000138463

Grant, J., Manuel, P., \& Joudrey, D. (1996). A framework for planning sustainable residential landscapes. Journal of the American Planning Association, 62, 331-345. http://dx.doi.org/ $\underline{10.1080 / 01944369608975698}$

Harrison County. (2008). 2030 Harrison County comprebensive plan. Harrison County, Mississippi: Author.

Hayden, D. (1981). The Grand Domestic Revolution. Cambridge, Massachusetts: MIT Press.

Hayden, D. (1986). Redesigning the American Dream: The future of housing, work and family life. New York, New York: Norton and Company.

Haeuber, R. (1998). Ecosystem management and environmental policy in the United States: Open window or closed door? Landscape and Urban Planning, 40, 221-233. http://dx.doi.org/10.1016/ S0169-2046(97)00115-1
Hernandez-Lopez, E. (2010). LA's taco truck war: How law cooks food culture contests. Social Science Research Network. Retrieved from http://papers.ssrn.com/ sol3/papers.cfm?abstract id $=1694747$

Innes, J. E. (1996). Planning through consensus building. Journal of the American Planning Association, 62, 460-472. http://dx.doi.org/10.1080/ $\underline{01944369608975712}$

Kaiser, E., Godschalk, D., \& Chapin, S. (1995). Urban Land Use Planning (5 ${ }^{\text {th }}$ edition). Chicago: University of Illinois Press.

Kirklin, J. (1995). Protecting species and ecosystems within planning process. Environmental Planning, 12(4), 6-13.

Laurien, L., Day, M., Berke, P., Ericksen, N., Backhurse, M., Crawford, J., \& Dixon, J. (2004). Evaluating plan implementation: A conformance-based methodology. Journal of the American Planning Association, 70(4), 471-480. http://dx.doi.org/ 10.1080/01944360408976395

Lindell, M. K., \& Perry, R. W. (1999). Household adjustment to earthquake hazard: A review of research. Environment and Behavior, 32(4), 590-630.

McGinnis, M., Woolley, J., \& Gamman, J. (1999). Bioregional conflict resolution: Rebuilding community in watershed planning and organizing. Environmental Management, 24(1), 1-12. http://dx.doi.org/10.1007/s002679900210

Mississippi Historical Society. (n.d.). The seafood industry in Biloxi: Its early history, 1848-1930. Mississippi History Now, the Mississippi Historical Society. Retrieved from the Mississippi Historical Society website: http://mshistory.k12.ms.us/articles/ 209/the-seafood-industry-in-biloxi-its-...2

Mississippi Department of Marine Resources (MDMR) and Office of Coastal Management and Planning. (2009). Mississippi Gulf Coast National Heritage Area Management Plan and Environmental Assestment. Bolixi, Mississippi.

Mississippi Renewal Forum. (2005). The People. Retrieved 19 April 2007 from http://www.mississippirenewal. com/info/people.html

Morales, A., \& Kettles, G. (2009). Healthy food outside: Farmers' markets, taco trucks, and sidewalk fruit vendors. The Journal of Contemporary Health Law and Policy, 26(20), 20-48.

National Oceanic and Atmospheric Administration (NOAA). (2007). Environmental impacts of Hurricane Katrina. Retrieved 19 April 2007 from http://www.st.nmfs.noaa.gov/hurricane katrina/press releases.html 
National Oceanic and Atmospheric Administration (NOAA). (2011). Safe and sustainable seafood supply. Retrieved from http://d276864.h39.zee-hosting. com/page. asp?id $=189$

Noss, R., \& Scott, M. (1997). Ecosystem protection and restoration: The core of ecosystem management. In M. Boyce \& A. Hanley (Eds.). Ecosystem management: Applications for sustainable forest and wildlife resources (pp. 239-264). New Haven, Connecticut: Yale University Press.

Norton, R. K. (2006). Managing development in coastal Michigan: What communities have, what they say they want, and what they'll likely get. Paper presented at the Association of Collegiate Schools of Planning, Fort Worth, Texas, November 9, 2006.

Paster, E. (2004). Preservation of agricultural lands through land use planning tools and techniques. Natural Resources Journal, 44(1), 283-318.

Peck, S. (1998). Planning for biodiversity: Issues and examples. Washington, D.C.: Island Press.

Pothukuchi, K., \& Kaufman, J. L. (2000). The food system: A stranger to the planning field. Journal of the American Planning Association, 66(2), 113-124.

Prater, C., \& Lindell, M. K. (2000, May). Politics of hazard mitigation. Natural Hazards Review, 1(2), 73-82. http://dx.doi.org/10.1061/(ASCE)15276988(2000)1:2(73)

Raja, S., Ma, C., \& Yadav, P. (2008). Beyond food deserts: Measuring and mapping racial disparities in neighborhood food environments. Journal of Planning Education and Research, 27(4), 469-482. http://dx.doi.org/10.1177/0739456X08317461

Roberts, P. (2006). Evaluating regional sustainable development: Approaches, methods and the politics of analysis. Journal of Environmental Planning and Management, 49(4), 515-532. http://dx.doi.org/ $\underline{10.1080 / 09640560600747786}$
San Francisco Department of Public Health. (2010). Healthy development measurement tool. Retrieved from http://www.thehdmt.org/

Sowman, M., \& Brown, A. L. (2006). Mainstreaming environmental sustainability into South Africa's integrated development process. Journal of Environmental Planning and Management, 49(5), 695-712. http://dx.doi.org/10.1080/ 09640560600849988

Srivastava, R., \& Laurian, L. (2006). Natural hazard mitigation in local comprehensive plans: The case of flood, wildfire and drought planning in Arizona. Disaster Prevention and Management, 153, 461-483. http://dx.doi.org/10.1108/09653560610669936

State of Mississippi. (1972). Mississippi Code of 1972 Section 17-1. Retrieved from Michie's Legal Resources website: http://michie.com/mississippi/ lpext.dll? $\mathrm{f}=$ templates\&fn $=$ main $-\mathrm{h} \cdot \mathrm{htm} \& \mathrm{cp}=$

Tinker, I. (1995). The urban street food trade: Regional variations in women's involvement. In E. N. Chow \& C. W. White (Eds.). Women, the family, and policy: $A$ global perspective. Albany, New York: SUNY Press.

Tinker, I. (1997). Street foods: Urban food and employment in developing countries. New York, New York: Oxford University Press.

Wondolleck, J., \& Yaffee, S. (2000). Making collaboration work: Lessons from innovation in natural resource management. Washington, D.C.: Island Press.

Yaffee, S., \& Wondolleck, J. (1997). Building bridges across agency boundaries. In K. A. Kohm \& J. F. Franklin (Eds.). Creating a forestry for the $21^{\text {st }}$ century (pp. 381-396). Washington, D.C.: Island Press. 


\section{Appendix}

\section{Table 1. Food Systems Evaluation Results}

\begin{tabular}{|c|c|c|c|c|c|c|c|c|c|c|c|c|c|c|}
\hline Indicator & Biloxi & D'lberville & Gulfport & $\begin{array}{l}\text { Long } \\
\text { Beach }\end{array}$ & $\begin{array}{c}\text { Pass } \\
\text { Christian }\end{array}$ & $\begin{array}{l}\text { Pasca- } \\
\text { goula }\end{array}$ & $\begin{array}{l}\text { Moss } \\
\text { Point }\end{array}$ & Gautier & $\begin{array}{l}\text { Ocean } \\
\text { Springs }\end{array}$ & $\begin{array}{l}\text { Wave- } \\
\text { land }\end{array}$ & $\begin{array}{l}\text { Bay St. } \\
\text { Louis }\end{array}$ & $\begin{array}{c}\text { Harrison } \\
\text { County }\end{array}$ & $\begin{array}{l}\text { Hancock } \\
\text { County }\end{array}$ & $\begin{array}{r}\text { Jackson } \\
\text { County }\end{array}$ \\
\hline \multicolumn{15}{|l|}{ A. Factual Basis } \\
\hline $\begin{array}{l}\text { Recognition of the } \\
\text { historical role of food } \\
\text { systems in the } \\
\text { community }\end{array}$ & 1 & 1 & 0 & 0 & 0 & 1 & 0 & 0 & 0 & 1 & 0 & 2 & 1 & 1 \\
\hline $\begin{array}{l}\text { Identification of physical } \\
\text { areas used for agricul- } \\
\text { ture and aquaculture }\end{array}$ & 2 & 0 & 2 & 0 & 0 & 1 & 1 & 2 & 1 & 1 & 1 & 1 & 1 & 1 \\
\hline $\begin{array}{l}\text { Identification of facilities } \\
\text { for seafood processing }\end{array}$ & 1 & 0 & 0 & 0 & 0 & 0 & 1 & 0 & 1 & 0 & 0 & 0 & 0 & 0 \\
\hline $\begin{array}{l}\text { Identification of physical } \\
\text { areas used for } \\
\text { mariculture }\end{array}$ & 0 & 0 & 0 & 0 & 1 & 1 & 0 & 0 & 1 & 0 & 0 & 1 & 1 & 0 \\
\hline $\begin{array}{l}\text { Identification of water } \\
\text { bodies }\end{array}$ & 2 & 2 & 2 & 1 & 1 & 2 & 1 & 1 & 2 & 1 & 1 & 2 & 1 & 1 \\
\hline $\begin{array}{l}\text { Identification of } \\
\text { employment in agricul- } \\
\text { ture, aquaculture, and } \\
\text { mariculture industries }\end{array}$ & 1 & 2 & 0 & 0 & 2 & 1 & 2 & 1 & 1 & 1 & 0 & 1 & 1 & 1 \\
\hline $\begin{array}{l}\text { Identification of physical } \\
\text { facilities that support } \\
\text { agri/aqua/mariculture } \\
\text { (such as boat launches, } \\
\text { harbors, ports, rail) }\end{array}$ & 1 & 0 & 2 & 1 & 2 & 1 & 2 & 1 & 2 & 0 & 1 & 2 & 1 & 1 \\
\hline $\begin{array}{l}\text { Identification of social } \\
\text { services that support } \\
\text { food access }\end{array}$ & 0 & 0 & 0 & 0 & 0 & 0 & 0 & 0 & 1 & 0 & 0 & 1 & 1 & 0 \\
\hline $\begin{array}{l}\text { Identification of food } \\
\text { waste }\end{array}$ & 0 & 0 & 0 & 0 & 0 & 0 & 1 & 0 & 0 & 0 & 0 & 0 & 0 & 0 \\
\hline
\end{tabular}




\begin{tabular}{|c|c|c|c|c|c|c|c|c|c|c|c|c|c|c|}
\hline $\begin{array}{l}\text { Recognition of climate } \\
\text { change and its potential } \\
\text { impacts on the food } \\
\text { system }\end{array}$ & 0 & 0 & 0 & 0 & 0 & 0 & 0 & 0 & 0 & 0 & 0 & 1 & 0 & 0 \\
\hline $\begin{array}{l}\text { Recognition that food is } \\
\text { a sustaining and } \\
\text { enduring necessity }\end{array}$ & 0 & 0 & 0 & 0 & 0 & 0 & 0 & 0 & 0 & 0 & 0 & 0 & 0 & 0 \\
\hline $\begin{array}{l}\text { Recognition that food } \\
\text { system activities take up } \\
\text { a significant amount of } \\
\text { land }\end{array}$ & 0 & 0 & 0 & 0 & 0 & 0 & 0 & 0 & 0 & 0 & 0 & 0 & 0 & 0 \\
\hline $\begin{array}{l}\text { Recognition that the food } \\
\text { system represents an } \\
\text { important part of } \\
\text { regional economies }\end{array}$ & 0 & 0 & 0 & 0 & 0 & 0 & 0 & 0 & 0 & 0 & 0 & 0 & 0 & 0 \\
\hline $\begin{array}{l}\text { Recognition of the fossil } \\
\text { fuel energy needed to } \\
\text { produce, process, trans- } \\
\text { port, and dispose of food }\end{array}$ & 0 & 0 & 0 & 0 & 0 & 0 & 0 & 0 & 0 & 0 & 0 & 0 & 0 & 0 \\
\hline $\begin{array}{l}\text { Recognition that water } \\
\text { pollution adversely } \\
\text { affects mariculture }\end{array}$ & 1 & 0 & 0 & 0 & 0 & 2 & 0 & 0 & 0 & 0 & 0 & 0 & 0 & 0 \\
\hline $\begin{array}{l}\text { Recognition that access } \\
\text { to healthy foods in low- } \\
\text { income areas is an } \\
\text { increasing problem }\end{array}$ & 0 & 0 & 0 & 0 & 0 & 0 & 0 & 0 & 0 & 0 & 0 & 0 & 0 & 0 \\
\hline $\begin{array}{l}\text { Promotion of a regional } \\
\text { food system to create } \\
\text { stronger communities }\end{array}$ & 0 & 0 & 0 & 0 & 0 & 0 & 0 & 0 & 0 & 0 & 0 & 1 & 0 & 0 \\
\hline $\begin{array}{l}\text { Identification of prevent- } \\
\text { able disease incidence } \\
\text { (asthma, diabetes, heart } \\
\text { disase, etc.) }\end{array}$ & 0 & 0 & 0 & 0 & 0 & 0 & 0 & 0 & 0 & 0 & 0 & 2 & 0 & 0 \\
\hline $\begin{array}{l}\text { Proportion of population } \\
\text { within } 1 \text { mile of a } \\
\text { supermarket }\end{array}$ & 0 & 0 & 0 & 0 & 0 & 0 & 0 & 0 & 0 & 0 & 0 & 0 & 0 & 0 \\
\hline
\end{tabular}




\begin{tabular}{|c|c|c|c|c|c|c|c|c|c|c|c|c|c|c|}
\hline $\begin{array}{l}\text { Proportion of retail food } \\
\text { establishments that } \\
\text { accept food assistance } \\
\text { programs }\end{array}$ & 0 & 0 & 0 & 0 & 0 & 0 & 0 & 0 & 0 & 0 & 0 & 0 & 0 & 0 \\
\hline $\begin{array}{l}\text { Proportion of public } \\
\text { schools with a school } \\
\text { garden }\end{array}$ & 0 & 0 & 0 & 0 & 0 & 0 & 0 & 0 & 0 & 0 & 0 & 0 & 0 & 0 \\
\hline $\begin{array}{l}\text { Density of fast food } \\
\text { outlets }\end{array}$ & 0 & 0 & 0 & 0 & 0 & 0 & 0 & 0 & 0 & 0 & 0 & 0 & 0 & 0 \\
\hline $\begin{array}{l}\text { Proportion of households } \\
\text { within } 1 \text { mile of a } \\
\text { farmers' market }\end{array}$ & 0 & 0 & 0 & 0 & 0 & 0 & 0 & 0 & 0 & 0 & 0 & 0 & 0 & 0 \\
\hline $\begin{array}{l}\text { Proportion of households } \\
\text { within } 1 \text { mile of a com- } \\
\text { munity garden, CSA, or } \\
\text { other food source }\end{array}$ & 0 & 0 & 0 & 0 & 0 & 0 & 0 & 0 & 0 & 0 & 0 & 0 & 0 & 0 \\
\hline $\begin{array}{r}\text { Total Score for } \\
\text { Factual Basis }\end{array}$ & 9 & 5 & 6 & 2 & 6 & 9 & 8 & 5 & 9 & 4 & 3 & 14 & 7 & 5 \\
\hline $\begin{array}{r}\text { Total Percentage Score } \\
\text { for Factual Basis }\end{array}$ & $18.8 \%$ & $10.4 \%$ & $12.5 \%$ & $4.2 \%$ & $12.5 \%$ & $18.8 \%$ & $16.7 \%$ & $10.4 \%$ & $18.8 \%$ & $8.3 \%$ & $6.3 \%$ & $29.2 \%$ & $14.6 \%$ & $10.4 \%$ \\
\hline \multicolumn{15}{|l|}{ B. Goals and Objectives } \\
\hline $\begin{array}{l}\text { Creating a sustainable } \\
\text { and more self-reliant } \\
\text { community and regional } \\
\text { food system }\end{array}$ & 0 & 0 & 0 & 0 & 0 & 0 & 0 & 0 & 0 & 0 & 0 & 2 & 0 & 0 \\
\hline $\begin{array}{l}\text { Supporting food systems } \\
\text { that are ecologically } \\
\text { sustainable }\end{array}$ & 0 & 0 & 0 & 0 & 0 & 0 & 0 & 0 & 0 & 0 & 1 & 0 & 0 & 0 \\
\hline $\begin{array}{l}\text { Supporting food systems } \\
\text { that improve the health } \\
\text { of the region's residents }\end{array}$ & 0 & 0 & 0 & 0 & 0 & 0 & 0 & 0 & 0 & 0 & 0 & 0 & 0 & 0 \\
\hline $\begin{array}{l}\text { Supporting food systems } \\
\text { that are equitable and } \\
\text { just }\end{array}$ & 0 & 0 & 0 & 0 & 0 & 0 & 0 & 0 & 0 & 0 & 0 & 2 & 0 & 0 \\
\hline
\end{tabular}




\begin{tabular}{|c|c|c|c|c|c|c|c|c|c|c|c|c|c|c|}
\hline $\begin{array}{l}\text { Strengthening the local } \\
\text { and regional economy by } \\
\text { promoting local and } \\
\text { regional food systems }\end{array}$ & 2 & 0 & 0 & 0 & 0 & 0 & 0 & 0 & 0 & 0 & 0 & 2 & 0 & 0 \\
\hline $\begin{array}{l}\text { Concentrating growth } \\
\text { away from agriculture }\end{array}$ & 0 & 0 & 0 & 0 & 0 & 0 & 0 & 2 & 0 & 0 & 0 & 0 & 2 & 0 \\
\hline $\begin{array}{l}\text { Supporting the } \\
\text { development of facilities } \\
\text { that support the food } \\
\text { system }\end{array}$ & 0 & 0 & 2 & 0 & 0 & 1 & 0 & 0 & 0 & 0 & 2 & 0 & 0 & 0 \\
\hline $\begin{array}{r}\text { Total Score for } \\
\text { Goals and Objectives }\end{array}$ & 2 & 0 & 2 & 0 & 0 & 1 & 0 & 2 & 0 & 0 & 3 & 6 & 2 & 0 \\
\hline $\begin{array}{r}\text { Total Percentage Score } \\
\text { for Goals and Objectives }\end{array}$ & $14.3 \%$ & $0.0 \%$ & $14.3 \%$ & $0.0 \%$ & $0.0 \%$ & $7.1 \%$ & $0.0 \%$ & $14.3 \%$ & $0.0 \%$ & $0.0 \%$ & $21.4 \%$ & $42.9 \%$ & $14.3 \%$ & $0.0 \%$ \\
\hline \multicolumn{15}{|l|}{$\begin{array}{l}\text { C. Policies, Tools, and } \\
\text { Strategies }\end{array}$} \\
\hline $\begin{array}{l}\text { Encouraging community } \\
\text { gardens }\end{array}$ & 1 & 0 & 0 & & 0 & 0 & 0 & 0 & 0 & 0 & 0 & 2 & 0 & 2 \\
\hline $\begin{array}{l}\text { Establishing urban } \\
\text { growth boundaries to } \\
\text { exclude food-growing } \\
\text { areas }\end{array}$ & 0 & 0 & 0 & 0 & 0 & 0 & 0 & 0 & 0 & 0 & 0 & 0 & 0 & 0 \\
\hline $\begin{array}{l}\text { Targeting growth away } \\
\text { from food sources }\end{array}$ & 0 & 0 & 0 & 0 & 0 & 0 & 0 & 0 & 0 & 0 & 0 & 3 & 0 & 0 \\
\hline $\begin{array}{l}\text { Making capital } \\
\text { improvements }\end{array}$ & 2 & 2 & 2 & 2 & 2 & 1 & 2 & 2 & 0 & 2 & 2 & 2 & 2 & 1 \\
\hline $\begin{array}{l}\text { Establishing } \\
\text { conservation zones or } \\
\text { overlay districts }\end{array}$ & 0 & 0 & 0 & 0 & 1 & 2 & 2 & 0 & 0 & 1 & 0 & 2 & 2 & 1 \\
\hline $\begin{array}{l}\text { Establishing buffer } \\
\text { requirements }\end{array}$ & 0 & 0 & 0 & 0 & 1 & 2 & 2 & 0 & 1 & 0 & 0 & 0 & 0 & 1 \\
\hline $\begin{array}{l}\text { Identifying commercial } \\
\text { districts (where restau- } \\
\text { rants and grocery are } \\
\text { located) }\end{array}$ & 1 & 0 & 0 & 0 & 1 & 1 & 0 & 0 & 0 & 0 & 0 & 2 & 0 & 0 \\
\hline
\end{tabular}




\begin{tabular}{|c|c|c|c|c|c|c|c|c|c|c|c|c|c|c|}
\hline $\begin{array}{l}\text { Encouraging Main Street } \\
\text { programs (to support } \\
\text { mom-and-pop } \\
\text { enterprises) }\end{array}$ & 0 & 0 & 0 & 0 & 0 & 0 & 0 & 0 & 0 & 0 & 0 & 2 & 0 & 0 \\
\hline $\begin{array}{l}\text { Establishing transit } \\
\text { options connecting low- } \\
\text { income areas with } \\
\text { supermarkets }\end{array}$ & 0 & 0 & 0 & 0 & 0 & 0 & 0 & 0 & 0 & 0 & 0 & 0 & 0 & 0 \\
\hline $\begin{array}{l}\text { Offering technical assis- } \\
\text { tance to food producers } \\
\text { to avoid adverse impacts } \\
\text { on water }\end{array}$ & 0 & 0 & 0 & 0 & 0 & 0 & 0 & 0 & 0 & 0 & 0 & 0 & 0 & 0 \\
\hline $\begin{array}{l}\text { Offering educational } \\
\text { facilities and/or } \\
\text { programming to support } \\
\text { food systems education }\end{array}$ & 0 & 0 & 1 & 0 & 0 & 0 & 0 & 0 & 0 & 0 & 1 & 0 & 0 & 0 \\
\hline $\begin{array}{l}\text { Building or rebuilding } \\
\text { farmers' markets }\end{array}$ & 0 & 0 & 0 & 0 & 0 & 0 & 2 & 0 & 0 & 0 & 2 & 2 & 1 & 0 \\
\hline $\begin{array}{l}\text { Encouraging urban } \\
\text { and/or suburban } \\
\text { agriculture }\end{array}$ & 1 & 0 & 0 & 0 & 0 & 0 & 0 & 0 & 0 & 0 & 0 & 2 & 0 & 0 \\
\hline $\begin{array}{l}\text { Regulating land use to } \\
\text { support working } \\
\text { waterfronts }\end{array}$ & 1 & 0 & 0 & 0 & 0 & 0 & 0 & 0 & 0 & 0 & 0 & 2 & 2 & 0 \\
\hline $\begin{array}{l}\text { Establishing a local food } \\
\text { purchasing policy }\end{array}$ & 0 & 0 & 0 & 0 & 0 & 0 & 0 & 0 & 0 & 0 & 0 & 0 & 0 & 0 \\
\hline $\begin{array}{l}\text { Creating a food vendor } \\
\text { cart ordinance }\end{array}$ & 0 & 0 & 0 & 0 & 0 & 0 & 0 & 0 & 0 & 0 & 0 & 0 & 0 & 0 \\
\hline $\begin{array}{l}\text { Establishing a transfer of } \\
\text { development rights } \\
\text { program }\end{array}$ & 1 & 0 & 2 & 2 & 2 & 0 & 0 & 0 & 0 & 0 & 0 & 0 & 0 & 0 \\
\hline $\begin{array}{l}\text { Encouraging cluster } \\
\text { development }\end{array}$ & 2 & 1 & 1 & 0 & 0 & 2 & 1 & 2 & 1 & 2 & 2 & 2 & 2 & 1 \\
\hline
\end{tabular}




\begin{tabular}{|c|c|c|c|c|c|c|c|c|c|c|c|c|c|c|}
\hline $\begin{array}{l}\text { Offering storm water } \\
\text { management credit for } \\
\text { providing agricultural } \\
\text { land on site }\end{array}$ & 0 & 0 & 0 & 0 & 0 & 0 & 0 & 0 & 0 & 0 & 0 & 0 & 0 & 0 \\
\hline $\begin{array}{l}\text { Offering incentives for } \\
\text { green roofs for urban } \\
\text { agriculture }\end{array}$ & 0 & 0 & 0 & 0 & 0 & 0 & 0 & 0 & 0 & 0 & 0 & 1 & 0 & 0 \\
\hline $\begin{array}{l}\text { Offering extra credit for } \\
\text { fruit trees as part of } \\
\text { landscaping } \\
\text { requirements }\end{array}$ & 0 & 0 & 0 & 0 & 0 & 0 & 0 & 0 & 0 & 0 & 0 & 2 & 0 & 0 \\
\hline $\begin{array}{l}\text { Offering incentives for } \\
\text { community supported } \\
\text { agriculture operations }\end{array}$ & 0 & 0 & 0 & 0 & 0 & 0 & 0 & 0 & 0 & 0 & 0 & 0 & 0 & 0 \\
\hline $\begin{array}{l}\text { Restricting fast food } \\
\text { restaurants }\end{array}$ & 0 & 0 & 0 & 0 & 0 & 0 & 0 & 0 & 0 & 0 & 0 & 0 & 0 & 0 \\
\hline $\begin{array}{l}\text { Allowing fruit and } \\
\text { vegetable carts on } \\
\text { sidewalks }\end{array}$ & 0 & 0 & 0 & 0 & 0 & 0 & 0 & 0 & 0 & 0 & 0 & 0 & 0 & 0 \\
\hline $\begin{array}{r}\text { Total Score for Policies, } \\
\text { Tools, and Strategies }\end{array}$ & 9 & 3 & 6 & 4 & 7 & 8 & 9 & 4 & 2 & 5 & 7 & 24 & 9 & 6 \\
\hline $\begin{array}{r}\text { Total Percentage Score } \\
\text { for Policies, Tools, and } \\
\text { Strategies }\end{array}$ & $16.7 \%$ & $5.6 \%$ & $11.1 \%$ & $7.4 \%$ & $13.0 \%$ & $14.8 \%$ & $16.7 \%$ & $7.4 \%$ & $3.7 \%$ & $9.3 \%$ & $13.0 \%$ & $44.4 \%$ & $16.7 \%$ & $11.1 \%$ \\
\hline $\begin{array}{r}\text { Total Normalized } \\
\text { Percentage Score } \\
\text { Across All Categories }\end{array}$ & $16.6 \%$ & $5.3 \%$ & $12.6 \%$ & $3.9 \%$ & $8.5 \%$ & $13.6 \%$ & $11.1 \%$ & $10.7 \%$ & $7.5 \%$ & $5.9 \%$ & $13.5 \%$ & $38.8 \%$ & $15.2 \%$ & $7.2 \%$ \\
\hline
\end{tabular}

